\title{
コンクリート工事中の管理ポイント一土木一
}

\author{
秋 元 泰 輔*
}

生コン使用にあたり，具体的な打設（打込みから養生 まで) 計画, 生コンの発注と受入れ, 運搬, 打込み, 締 固め, 養生等については他稿に述べられているので, こ こでは主に，これらの施工の各段階において適正な管理 を行うための着眼点(チェックポイント)について, コン クリート打設準備, 打設中及び打設後に分けて述べる。

1.コンクリート打設準備における管理 ポイント

コンクリート打設準備段階においては, 打設中及び打 設後の管理に支障とならないように，一般に次の点をチ エックする。

1）工事仕様書, 特記仕様書, 設計図面, 設計計算書, 材料計算書等の内容

2）施工計画書，コンクリート打設作業計画書（施工 計画書では示せない，より具体的なコンクリート打設作 業に関する計画書) の内容

3）工事現場の状態（打設準備状態，打設用機械器具 の準備と整備状況等), 生コン運搬車の搬入径路の状態, 安全対策, 公害対策等の状態

4) 生コンの品質 (JIS A 5308 レデーミクストコン クリートに示される配合報告書の内容), 生コン工場 と の連絡体制，生コンの手配準備（打設量，打設開始時間 及び終了時間, 運搬車 の配車等), 品質管理・検查方法 (検査の内容, 時期, 回数, 方法等) など

5）型わくの位置，堅牢性（支保工，フォームタイ， スペーサ等), 表面の状態など

6) 鋼材 (鉄筋, P C 鋼材等) の品質, 鋼材の寸法 (直 径, 長さ, 加工等), 位置 (本数, 最小間隔, 最小かぶ り厚さ等), 定着及び継手の位置や状態（重ね継手長， ガス圧接部の外観等), 堅牢性 (結束, スペーサ), 清浄 性（浮き錆のないこと, 油, ペイント, 乾燥したモルタ ル等が付いていないこと等) など

7）コンクリート構造物内に設置される埋設物の位 置, 安定性, 清浄性など, 及び型わく取出し用の開孔位

* 正会員 首都高速道路公団第 1 建設部設計課課長補佐
置など

8）現場代理人, 主任技術者, コンクリート打設責任 者（コンクリート打設中は常に立ち合い，特にコンクリ ートの品質について常に目視により管理する責任者), 職員, 作業員の任務の分担及び人員配置

9）その他，非常時のための対策（降雨の際の防護シ ート, 夜間照明, 強風, 停電等に対する対策等) など

1) のチェックにより打設するコンクリート構造物に ついてあらかじめ検討する。設計計算に誤りがあった場 合，工事をいくら完全に行っても欠陥が生じ，取り壊し， 再構築しなければならなくなる場合むある。2）には,コ ンクリートの打込み方法, 打込み順序, 養生方法等が示 されており、コンクリート打設前に内容を十分チェック することで, 適正なコンクリート打設及び管理体制が確 立される。3）のチェックにより，現場におけるコンク リート打設準備が完了しているか確認する。4) のチェ ックにより, 計画どおりの生コン搬入が可能となる。な お，コンクリートの呼び強度と設計基準強度との関係を 確認しておくのがよい（一般には等しい）。5）のチェッ クは,いわゆる型わく検査の内容である。型わくの凹凸， 穴, 剝離剤等の不良は, コンクリート表面の剝離, 砂, 気泡等の欠陥（図一1 参照）の原因となる。また型わく が堅牢に組み立てられていないと, はらんで危険な状態 になり, また所定の形状, 寸法の構造物が得られない原 因となる。型わくの継目も隙間があかないようにしない と, セメントペーストが流出して, 豆板, 砂, 縞, 場合 によってはじゃんかのような欠陥（図一1 参照）の原因 となる。支保工は，若干沈下するのはやむを得ないが， 異状な沈下はコンクリート構造物に重大な影響を与え, 場合によっては取壞し, 再構築の原因ともなる。なお, 型わく設置精度のチェックの目標值の一例として, 表一 1 に道路橋示方書而コンクリート橋編 (建設省, 以下道 示而と言う）に示される部材寸法の施工精度の標準值を 示す。6) のチェックは, いわゆる配筋検查の内容であ る。鋼材の品質は, 高炉製品の鉄筋及び P C 鋼材につい ては品質規格証明書, いわゆるミルシートによりチェッ 


\section{表一1 部祆寸法の施工精度（道示正より）}

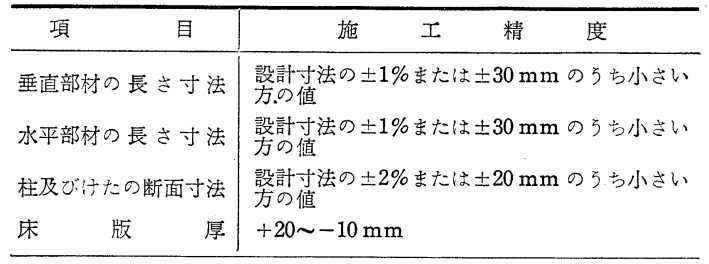

表一2 鋼材配置に関する施工精度（道示而より）

(1) 鉄筋配置に関する施工精度

\begin{tabular}{|c|c|c|c|c|}
\hline 項 目 & 施 & I & 精 & 度 \\
\hline 有効高さ & \multicolumn{4}{|c|}{$\begin{array}{l}\text { 設計寸法の } \pm 3 \% \text { または } \pm 30 \mathrm{~mm} \text { のうち小さい方の值。 } \\
\text { ただ最小かぶりは確保するものとする。 }\end{array}$} \\
\hline
\end{tabular}

（2） $\mathrm{P} \mathrm{C}$ 鋼材配置に関する施工精度

\begin{tabular}{|c|c|c|c|c|}
\hline 項 & 目 & 施 & 精 & 度 \\
\hline \multirow{2}{*}{$\begin{array}{l}\text { P C 鋼材中 } \\
\text { 心と部材縁 } \\
\text { との距離 }\end{array}$} & $\begin{array}{l}\text { 主要な設計 } \\
\text { 断面の両側 } \\
l / 10 \text { 䈥田 } \\
(l: \text { 支間 }\end{array}$ & \multicolumn{3}{|c|}{$\begin{array}{l}\text { 設計寸法の } \pm 5 \% \text { または } \pm 5 \mathrm{~mm} \text { のうち小 } \\
\text { さい方の值。 }\end{array}$} \\
\hline & $\begin{array}{l}\text { その他の範 } \\
\text { 国 }\end{array}$ & \multicolumn{3}{|c|}{$\begin{array}{l}\text { 設計寸法の } \pm 5 \% \text { または } \pm 30 \mathrm{~mm} \text { のちち小 } \\
\text { さい方の値。 } \\
\text { ただし最小から゙りは確保するものとする。 }\end{array}$} \\
\hline
\end{tabular}

クすればよいが，電炉製品の鉄筋については，JIS 製品 といえども問題のあるものもあり，ミルシートのチェッ クのほかに, 引張試験及び曲げ試験により品質の検査を 行うのがよい。ガス圧接部も，外観のみでなく，抜取検 查により, 引張試験及び曲げ試験を行うか，全数超音波 探傷検査により圧接部の品質の確認を行う必要がある。 配筋状態については，コンクリート標準示方書（土木学 会）に示される最小閒隔，最小かぶり等によりチェック する。なお，鋼材配置精度のチェックの目標值の一例と して, 表一2 に道示亚に示される鋼材配置に関する施工 精度の標準值を示す。適切に配筋されないと，コンクリ 一ト打込みが困難になり, 締固めも十分に行えず, 密に 配置されている鉄筋部にコンクリートの粗骨材がスクリ ーンされ，その結果，材料分離を起こしてじゃんかを作 る（スクリーニング，図一1 参照）等の欠宿の原因とな る。7）のチェックは配筋検査の際に行う。8）によりコ ンクリート打設時の人員配置等をチェックし，9）によ り非常時のための対策等をチェックして，コンクリート 打設準備段階のチェックが終わる。

2. コンクリート打設中における管理 ポイント

コンクリート打設中の管理のためのチェックは，打設 作業の流れによって，それぞれの作業別に行われるもの とコンクリートの品質について行われるむの（受入れ検 查，品質管理）とに大別される。打設後の管理（検查） で問題なく合格し, 補修等む行わなくてもすむように十 分チェックする必要がある。

\section{1 打設作業の流れによる管理ポイント}

打設作業の流れに従い，一般に次の点をチェックす る。

\section{（1）生コンの般入}

(1)生コン運搬車の搬入路の状態, (2)生コン運搬車の手 配の状況（打込み速度に合う配車, 運搬途中の交通沙滞 によるトラブル等のほかに, 打込み終了時に, 最終打込 量の調整で, 連続打設, 適切な締固め及び仕上げができ ずにトラブルを起こす例があるので，適切な対処が必 要)，(3)運搬車の確認 (JIS A 5308 に示される納入書に よるチェックで誤配を防ぐ)。

\section{（2）コンクリート打込み}

(1)打込み方法の確認（打込み用機械器具の状態, 人員 配置等), (2)打込み順序の確認（コンクリートが分離し ないような順序, 打継目の少ない順序, 打込み完了のコ ンクリートにひびわれを生じさせるような有害な振動を 伝えにくく，また有害なたわみの影響を与えないような 順序等)，(3)打込み速度の確認（コンクリートの側圧に よって型わく, 支保工が有害な変形をしない程度の速 度, コールドジョイントができない程度の速度, コンク リートの沈降収縮によるひびわれ（図一1 参照）が生じ ないような程度の速度等), (4)打込み状態の確認 (1 箇 所に多量のコンクリートを打ち込まない。鉛直に落と す。落下距離は $1.5 \mathrm{~m}$ 程度以内とする。低い位置から 落とす。コンクリートを横流ししない。15 $30 \mathrm{~cm}$ 程度 の均等厚に水平に打ち込む。各層を平らにならし, 十分 締め固めてから次の層を打ち込む。各層間にコールドジ ョイントが生じないように，コンクリートの練上り後 1 ２時閒以内に次の層を打ち込む。等, 材料分離を生じ させないのが原則)。

\section{(3) 締 固 め}

締固め状態の確認（棒状振動締固め機を $50 \mathrm{~cm}$ 程度 の間隔で均一に，かつ，既に打ち込まれたコンクリート 層に $10 \mathrm{~cm}$ 程度入るように鉛直に差し込み, コンクリ 一トの表面にセメントペーストがうっすらと浮き上がる 程度まで締め固め, 引抜き跡が残らない上うにゆっくり と引き抜く。締固め不足はあらゆる久陷を生じさせる原 因となるので，十分な締固めが必要)。

\section{(4) 仕 上げ}

(1)型わくに接しない面に対する仕上げ方法の確認（所 定の高さ及び形状寸法に仕上げる。仕上げ面に浮き出た ブリージングの水がなくなった後か, ブリージングの水 を処理した後に仕上げる。仕上げは木ごてで行うのを原 則とする。仕上げ後 1 3 時間でひびわれ等が発見され た場合,再仕上げを行う等), (2)型わくに接する面に対す る仕上げ方法の確認（棒状振動締固め機で型わくの隅々 まで十分締め固める等。なお, 型わくを外した後の仕上 
げについては, 後述の外観検査の項も参照されたい)。

\section{（5）養生}

(1)養生状態の確認（常に湿潤状態で，養生を行う。十 分に養生を行わないと乾燥収縮によるひびわれが生ずる 原因となる。また，過度の荷重，振動，衝撃，温度変化 等によって工事中のコンクリート構造物に有害な応力を 生じさせない。等)，(2)養生期間の確認（普通ポルトラン ドセメントを用いたコンクリートの場合は少なくとも 5 日間，早強ポルトランドセメントの場合は 3 日間以上と する)，(3)型わくを外す時期の確認（土木学会のコンク リート標準示方書では, 部材面の種類別に型わくを取り 外してよい時期のコンクリートの圧縮強度の参考値が示 されている。一般に，はり等のように自重により曲げを 受ける部材は，その影響の程度によりコンクリート材令 7〜21 日，柱などのように自重により曲げを受けない部 材はコンクリート材令 1〜7 日で型わくが外される)。

\section{(6) その他}

(1)打継目の処置の確認（適切な処理をとらないとじゃ んか等の欠陥を生じさせる原因となる)，(2)打設中に 鉄 筋，型わく，支保工の状態の確認（事前に型わくのはら み，鉄笳組立てのくずれ等を防ぐ)，(3)非常時における 対処の確認（コンクリート打設途中の降雨に対して，適 切な打継目の設置，仕上げ，防護シートの設置等の対処 等) など。

\section{2 コンクリートの品質管理}

コンクリートの品質に関する管理は，現場における生 コン搬入時の検查（受入れ検查）及び生コン搬入時に製 作した供試体（テストピース）の圧縮強度試験による管 理とに分けられ，これらが適切に行われているかをチェ ックする。

これらの管理（検査）について次に述べる。なお，最 近コンクリート品質の早期判定に関する種々の特殊管理 方法が提案されているので，それらについても概要を紹 介する。

\section{（1）生コン搬入時の検査（受入れ検査）}

従来, 一般的に行われている受入れ検查について次に 示す。

1） スランプ検查：JIS A 5308 では，スランプ検查 の試験方法は示されているが，試験回数は示されていな い。スランプ検査は，一般には運搬車 5 台に 1 回程度行 われているが，ある程度，スランプ検查で早期における

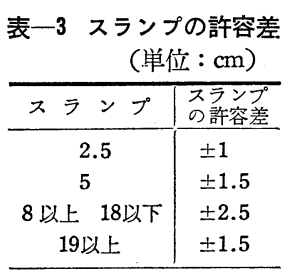

\section{表一4 空気量の許容差}

\begin{tabular}{l|l}
\hline コンクリートの種類 & 空気量の許容差 $\%$ \\
\hline 普通コンクリート & 指定した值の \pm 1 \\
軽量コンクリート & 指定した值の \\
\pm 1.5
\end{tabular}

コンクリートの品質管理が可能であるので，道示且解説 では運搬車 1 台に 1 回行うように示されている。なお， 後述 4) で述べる目視検查を行うコンクリート打設責任 者は，スランプ検査に必ず立ち合わなければならない。

試験結果の值が表一3 に示されるスランプの許容差内 であるかをチェックする。許容差を超えるものは不合格 とし，その運搬車のコンクリートは使用せずに，その車 両番号をメモしておき，必ず返却させる。不合格が続く 場合は，生コン工場の品質管理状態を確認し，配合等を 検討する必要がある。

2）空気量検查 : 空気量の検査は，一般に圧縮強度試 験用供試体製作のためにコンクリートの資料を採取する 際に行われる。試験方法は JIS A 5308 に示される方法 による。

試験結果の值が表一 4 に示される空気量の許容差内で あるかをチェックする。

3）単位容積重量検査：必要に応じて行われる。軽量 コンクリートの場合に行われる場合が多い。空気量検査 が行われる際に行う。

計算で求められる単位容積重量に対し，試験結果が士 $0.05 \mathrm{t} / \mathrm{m}^{3}$ 以内であるかをチェックする。

4）目視検查：1〜3）の検查は，一般に搬入される すべてのコンクリートについて行われないので, 必ず 1. の 8) で述ベたコンクリート打設責任者（コンクリート についての知識が豊富な技術者）がすべてのコンクリー トの品質について，目視によりチェックするのがよい。 常に運搬車から排出されるコンクリートを見ていれば， 品質に異常が生じた場合，発見できるものである。

一般に行われる以上のチェック，特に 4）と 1）のチ エックは，コンクリートの品質の異常を確認することが でき，受入れ検査としては有効である。ただし，異常の 原因や配合及び強度の確認はできず，次の（2）で述べ る圧縮強度試験による品質管理が必要となる。

\section{（2） 圧縮強度試験による管理}

JIS A 5308 では，圧縮強度の試験方法及び試験回数 が示されている。原則として $150 \mathrm{~m}^{3}$ につき 1 回（一般 には，同一コンクリートで同一構造物について最低 3 回 行うようにしている）試験を行い，1回の試験結果は任 意の 1 運搬車から採取した試料で作った 3 個の供試体の 試験值の平均值で表している。

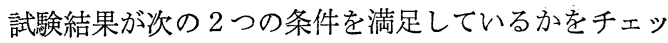
クする。

1） 1 回の試験結果は，指定した呼び強度の 值の 85 \% 以上でなければならない。

2）連続する 3 回の試験結果の平均值は，指定した呼 び強度の值以上でなければならない。

生コンの品質検查成績表の様式を表一5 に示す。 
表一5 生コンクリートの品質検査成繢表

昭和○年○月○日から昭和○年○月○日まて

\begin{tabular}{|c|}
\hline 合 格 \\
\hline 合 格 \\
\hline
\end{tabular}

\begin{tabular}{|c|c|c|c|}
\hline 事 & 構 造 物 & 請負業者名 & 生コン業者名 \\
\hline 0000I区0000000工事 & 橋 脚 & 000000 & 0000 \\
\hline
\end{tabular}

\begin{tabular}{|c|c|c|c|c|c|c|}
\hline \multirow{2}{*}{$\begin{array}{l}\text { コンクリート } \\
\text { の品質特性 }\end{array}$} & 生コン名 & 呼び強度 & 最低必要強度 & 粗骨材の最大寸法 & スランプ & 空 気 量 \\
\cline { 2 - 8 } \\
\cline { 2 - 7 } \\
\hline
\end{tabular}

\begin{tabular}{|c|c|c|c|c|c|c|c|c|}
\hline \multirow{2}{*}{ 配 合 } & \multirow{2}{*}{$\begin{array}{l}\text { 水セメン } \\
\text { 卜 比 }\end{array}$} & 細骨材料率 & \multicolumn{5}{|c|}{ 単 位 量 $\left(\mathrm{kg} / \mathrm{m}^{3}\right)$} \\
\cline { 5 - 9 } & 各社 & $54.0 \%$ & $41.5 \%$ & 149 & 276 & 789 & $1 / 13$ & 0.698 \\
\hline
\end{tabular}

\begin{tabular}{|c|c|c|c|c|c|c|c|c|c|}
\hline \multirow[b]{2}{*}{ No. } & \multirow{2}{*}{$\begin{array}{l}\text { 採月取 } \\
\text { 年月至 }\end{array}$} & \multirow{2}{*}{ スランプ } & \multirow{2}{*}{ 空気量 } & \multirow{2}{*}{$\begin{array}{l}\text { 単位容積 } \\
\text { 重 量 }\end{array}$} & \multicolumn{4}{|c|}{ 压縮強度 $\left(\mathrm{kg} / \mathrm{cm}^{2}\right)$} & \multirow{2}{*}{ 備 考 } \\
\hline & & & & & $\mathrm{X}_{1}$ & $\mathrm{X}_{2}$ & $\mathrm{X}_{3}$ & 平均值 & \\
\hline 1 & 00.00 .00 & $8.5 \mathrm{~cm}$ & $4.1 \%$ & $2328 \mathrm{~kg} / \mathrm{m}^{3}$ & 280 & 291 & 283 & 285 & P. $/ 59$ 橋脚 $\sigma_{28}$ \\
\hline 2 & " & $9.0 \mathrm{~cm}$ & $3.8 \%$ & $2330 \mathrm{~kg} / \mathrm{m}^{3}$ & 281 & 274 & 286 & 280 & \\
\hline 3 & " & $9.5 \mathrm{~cm}$ & $3.5 \%$ & $2335 \mathrm{~kg} / \mathrm{m}^{\mathrm{s}}$ & 284 & 294 & 299 & 292 & $\begin{array}{l}\text { No. I } 1 \text { No. } 3 \\
\text { O平均值 } 286 \mathrm{~kg} / \mathrm{cm}^{2}\end{array}$ \\
\hline 4 & "I & $9.0 \mathrm{~cm}$ & $3.9 \%$ & $2328 \mathrm{~kg} / \mathrm{m}^{3}$ & 275 & 280 & 283 & 279 & 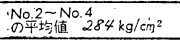 \\
\hline
\end{tabular}

貝殼などが含まれる場合は適 用できない。

この方法の応用として, 同 ビモルタル試料のセメント空 隙比を測定し，これを指標と してコンクリートの圧縮強度 を推定する方法がある。

2）遠心脱水方法 : 遠心脱 水機を用いてモルタルまたは コンクリート中の水をほぼ一 定の状態まで脱水して, 脱水 前後の重量差から水量を求め る。次に脱水物を特殊ろ布の 上に置き，水を注ぎながら洗 い，これを脱水して，脱水前 後の重量差からセメント量を 求め, 水セメント比を算出す る。所要時間は 2 人で 30 分

圧縮強度の試験結果はコンクリートの材令が 28 日の 值であり, この時点に不合格と判定されても一般に対処 するのが非常に困難であるので, 建設省, 公団等ではな るべく早期にコンクリートの品質（強度）をチェックす ベく, 材令 7 日の圧縮強度試験を行い, 強度上疑義があ る場合には, 品質が確認されるまで一時, 当該生コンの 使用を中止させるようにしている。

\section{（3）特殊管理方法}

上述のように，圧縮強度試験による管理は，コンクリ 一トの材令が早くても 7 日は必要で, その時点でも, 打 ち込まれたコンクリートは既に硬化しているので，管理 結果が不合格となっても, 一般に対処が非常に困難とな る。

従って, 何とかより早期にコンクリートの品質を確認 することができないかということで, 種々の研究がこれ までになされている。まだ, 従来の品質管理に代わって 採用されるまでには至っていないが，中には現場で実用 化実験を行って, それに近い状態まで検討されているも のもある。次に, これらコンクリートの品質の早期判定 方法に関する概要*を紹介する。

1）塩酸溶解熱方法 : 簡単な断熱容器を用い, コンク リートからふるい分けたモルタル資料を一定量の水で薄 めた希釈液に塩酸を加えて反応させ, 発生する発熱量が セメント量と比例することから水セメント比を測定す る。所要時間は 25 分程度で, 測定精度はコンクリート の水セメント比で $2 \%$ 以内である。細骨材に石灰石や

* コンクリート品質の早期判定研究委員会: コンクリート品質 の早期判定方法に関する概況, コンクリート工学, Vol. 17, No. 1, 1979.1 より
程度で, 測定精度は水セメント比 $3 \%$ 以内である。骨材 中の泥分量をあらかじめ試験しておいて補正する必要が ある。

3）洗い分析方法：まだ固まらないコンクリートを水 洗いして, $0.088 \mathrm{~mm}$ または $0.15 \mathrm{~mm}$ ふるいを通過す る量を求め, これからセメント量を測定する。この方法 には JIS A 1112(まだ固まらないコンクリートの洗い分 析試験方法）と自動洗い分析機による方法とがある。前 者は測定精度を上げるには試験に熟練を必要とするが, 後者はすべて機械が自動的に行い,所要時間は 2 人で 30 分程度であり, セメント量の試験精度 は $2.5 \%$ 以内で ある。骨材中の泥分量をあらかじめ試験しておいて補正 する必要がある。

4）比重計法: モルタルを一定量の水で希釈し, セメ ントを懸濁状態とした混合液の比重は, ボーメ比重計ま たは石油用比重計で測定することができ，その比重は懸 濁液中のセメント量に実用上比例するので, セメント量 を測定することができる。更に，水量をモルタルの加熱 乾燥による前後の重量差から求めるか, またはモルタル の空中重量及び水中重量を測定して, セメント量既知, セメントと細骨材それぞれの比重を既知として求めて水 セメントを算出する。提案者により細部を工夫した多く の試験方法がある。

5）炎光光度による方法 : コンクリート試料をふるい で洗い分析してセメント懸濁液を作り, 液中のセメント 粒子を硝酸で溶解し, カルシウムイオン濃度を炎光光度 計で分析して, あらかじめ用意したセメント標準溶液に よる検量線からセメント量を求める。水量は, コンクリ 一ト試料に一定濃度の塩化ナトリウム溶液を加えてよく 
擋拌した後, 上澄液をとって希釈された塩化ナトリウム の濃度をチオシアン酸カリ標準液で逆滴定して求める。 また, 炎光光度計を利用した自動化の方法を検討し, 水 量を硝酸銀の直接滴定によって濃度差から求めて水セメ ント比を測定する方法もある。

6）逆滴定による方法：コンクリート試料からふるい 分けたモルタル中のセメントを塩酸で溶解し, フェノー ルフタレインを指示薬として, 濃度既知の水酸化ナトリ ウムを用いて過剩の酸を逆滴定し, 酸消費量からセメン 卜量を求め, 水量はガスコンロを用いてモルタルを絶乾 にし, 乾燥量から骨材の吸水量を差し引いたものを有効 水量として求める。

7）急速硬化方法：約 $5 \mathrm{~kg}$ のコンクリートを採取 し， $5 \mathrm{~mm}$ ふるいでウエットスクリーニングして，これ から $500 \mathrm{~g}$ のモルタル試料を計り取る。これに $6 \mathrm{~g}$ 程 度の一定量の急結性薬剂を添加して 1 分間練りまぜ, 直 ちに専用型わくに詰める。これを $70^{\circ} \mathrm{C}, 100 \% \mathrm{RH}$ に保 たれている恒温恒湿装置に入れ，1 時間以上の一定時間 養生して急速硬化モルタル供試体を作製し, 圧縮試験を 行い, その結果から, あらかじめ求めておいた推定式を 用いて材令 28 日のコンクリートの強度を推定する。種 々の現場で試験的に管理を行った結果, 実際のコンクリ 一ト材令 28 日の庄縮強度と養生時間 1.5 時間の供試 体より得られた材令 28 日の圧縮強度の推定值との比の 変動係数は $8 \%$ であった。

8）煮沸方法：供試体成形後 30 分で型わくに密閉ぶ たを取り付けて約 $40^{\circ} \mathrm{C}$ の温水中に浸し, 30 分後に $100^{\circ} \mathrm{C}$ にして 3 時間煮沸養生を行った後, 水を加えて水 温を約 $50^{\circ} \mathrm{C}$ に下げ， 30 分間槽内で徐冷してから強度試 験を行う即日法と, 成形した供試体を $1 \sim 4$ 時間前置養 生した後, 防水袋に納めた型わくごとの供試体を沸騰水 に浸して 20〜23 時閒煮沸養生し, 水槽より取り出して 泠却, 脱型, キャッピングを行い, 1 2 時閒後に強度試 験を行う翌日法とがある。これらの方法によって得られ た強度と材令 28 日の強度との相関関係から材令 28 日 の強度を推定するが，季節や使用材料などによってこの 相関関係は異なる。

9) 温水方法 : 温水中で供試体を促進養生し, ごく早 期に強度試験を行う方法で, 温水方法は定温制御装置と その管理を必要とし，また養生時間を長くする必要か ら, 一般に強度試験は翌日以降となる。養生条件の差に より数種類の方法がある。煮沸方法に比べ, 温度ショッ クが小さく, ばらつきも少ない。また, 温度が低いほど 火傷の恐れがなく扱いやすい。

10）自熱方法：セメントの水和熱を利用して供試体 の促進養生を行い，早期に強度試験を行う方法で, 養生 装置としては断熱性の高い容器があればよい。試験は 3
日後程度になり, セメントの種類, セメント量, 外囲温 度等，促進強度への影響因子が多く，かつそれらの影響 が大きいため, 十分なデータによる補正が必要である。

$$
\begin{aligned}
\text { 3. コンクリート打設後における管理 } \\
\text { ポイント }
\end{aligned}
$$

工事中におけるコンクリート打設後の管理は, 一般に 外組検查及び出来形検査を行うことによりチェックす る。これらの検査の結果不合格となった場合には, 更に 強度検査を行う場合がある。なお, 使用材料の品質結果 によって強度検查を行う場合もある。

これらの検査の結果不合格となった場合は, 補修（原 設計に近い機能に修復する), 補強(設計・施工上の誤り による機能低下を向上させる場合も含め, 原設計以上の 機能に補修する）あるいは取壊し，再構築が行われる。 どの方法が採用されるかは検查結果にもより，一概に述 ベられないが，いずれにしても前記 1 . 及び 2 . に述べ ているように，それぞれの管理を十分に行い，不合格と ならないように早めに対処すべきである。

次に, 外観検查, 出来形検查及び強度検査について述 ベる。なお，工事完了後に維持管理がなされるが，ここ では省略する。

\section{1 外観検査}

外観検査は, コンクリート構造物の表面を見て, 久陥 (図-1 参照) の有無, 表面の凹凸, 型わく錆の付着の 有無, コンクリートの色あい, 仕上げ状態, 表面の緻密 さ，異物の有無等のチェックを行う。

外観検査で, 次に述べる程度の補修ですむ欠陷等が発 見された場合は，直ちに補修（型わくに接する面に対す る仕上げでもある)を行う。

1）表面が型わくの錆の付着等で污れている場合は, 砥石で磨いたり，サンドペーパ，サンドブラスト等を用 いて清掃する。

2）スペーサ，番線等の異物が表面に現れ，有害と思 われるものは適当な処置を行う。例えば, 鉄製のスペー サが表面に現れた場合は，錆止めペイントを塗布するな どの処置を行う。有害な異物が容易に取り除けるものは 取り除く。

3）仕上げ未完了の部分が発見されたならば，直ちに 仕上げる。例えば, ホームタイの穴の跡埋めには, 構造 物のコンクリートの配合から粗骨材を除いたモルタルを 用いて行う。この場合, 外観上から, まわりのコンクリ 一トの色に合わせるように色調に注意してモルタルを練 るのがよい。

4) 気泡穴や砂縞除去後の跡, 簡単な傷, 凹み等の充 填には, セメント 1 に対し $0.66 \mathrm{~mm}$ ふるいを通過する 砂 2 の割合からなる, 濃いクリーム状のスラリーを塗布 


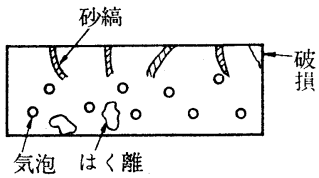

（1）砂縞, 気泡, 剝離及び 破損

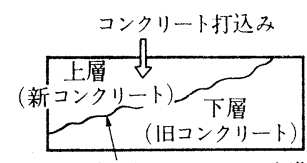

処理されていない打継目

あるいはコールドジョイント

（3）処理されていない打継目及び コールドジョイント

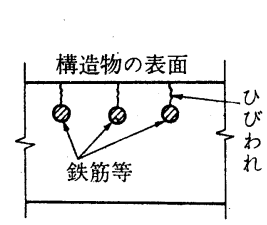

（5）コンクリートの沈降によるひびわれ及び 支保工の沈下などによるひびわれ

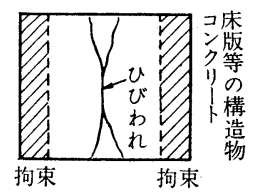

（6）乾燥収縮あるいは温度応力 によるにびわれひ

図一1 コンクリート構造物の欠陷

するとよい。この場合も, 適当に白色セメントを混入し てまわりのコンクリートの色に合わせるようにするとよ い。

5）剝離部，破損部及び豆板，ビゃんかを取り除いた 部分には, 硬練りのモルタル（セメント 1 に砂 2 の割 合）をパッチングするとよい。

6） 久陥の補修に用いたモルタルが施工不良により浮 いている場合が多いので，直ちにその浮いたモルタルを 取り除き，再補修を行う。

\section{2 出来形検查}

出来形検査は, 次に述べる構造物の位置, 形状, 寸法, 機能等のチェックを行う。

（1）構造物の位置, 形状, 寸法等の検査

位置，形状，寸法等は，設計図面どおりになっている かをチェックするが，一般に設計図面どおりには工事で きないので，実際には許容誤差の範囲内にあるかをチェ ックする。

許容誤差については, 構造物の種類, 立地条件, 重要 度等によるほか，発注者側の条件にもよる。ただし，い かなる場合も建築限界（道路に関しては「道路構造令」, 鉄道に関しては「建造物基本構造基準規程」等，河川に 関しては「河川管理施設等構造令」等に示されている),
用地境等は絶対に侵してはならない。

表一1 に許容誤差の例を示す。構造物は許容誤差 以内になければならず, この許容誤差を侵したもの は原則として取り壊し，再構築となる。

\section{(2) 構造物の機能等の検査}

構造物の伸縮目地，排水装置，橋の支承等の機能 が完全に働くようになっているかをチェックする。

これら構造物に設置されるものが何のために設置 されているのかを，あらかじめ検討して工事を行 い，その機能が十分に発揮できるようにしておかな ければならない。チェックの結果, 機能が十分に発 揮できない場合は, 発揮できるように処置しなけれ ばならない。

\section{3 強度検查}

外観検査及び出来形検査の結果によるほか, 使用 材料の品質管理の結果によって, 構造物が所定の品 質のものであるかを強度検査によって更にチェック する場合がある。

強度検查には，(1)構造物の非破壊試験，(2)構造物 から資料を採取して行うコア試験，(3)構造物の載荷 試験がある。強度検查を行う目的により,これらの ぞの試験を行えばよいかを検討すればよい。

\section{(1) 非破壊試験}

非破壊試験は構造物を破壊しないで，打ち込まれ 硬化したコンクリートの強度のチェックを行う。テスト ハンマを用いて，経験のある検查員がコンクリート表面 をたたいて，は衫返りの程度, 音等によりコンクリート の強度を推定する(この方法によりじゃんか等の久陥も 発見できる）方法から，シュミットハンマを用いてコン クリート表面を打撃し, その反発硬度を測定して圧縮強 度を測定する方法，超音波を送り，はね返りの波の状態 を測定してコンクリートの強度（強度というより，弾性 係数を調へ，強度に換算している）を推定する方法等が ある。機械のキャリブレーションの問題, コンクリート 中の鉄筋，骨材等の影響などにより精確に強度を推定す ることはできないが，ある程度の判断はできる（これら 種々の方法を組み合わせて行うと精度は上がる)。

\section{（2）構造物より資料を採取して行うコア試験}

強度的に問題のある部分から資料を採取して強度試験 を行う。一般には，コアを採取して圧縮強度試験を行っ ている。

コアの採取には十分注意しないと，構造物に悪影響を 与えるとともに，コア自身にも悪影響を与え，的確な強 度が得られない。次にコア採取にあたっての注意事項を 述べる。

1）構造物中の鋼材に当たらないようにコア採取の位 
表一6 圧縮強度補正係数 (JIS A 1107)

\begin{tabular}{c|c|c}
\hline \begin{tabular}{c|c} 
高さと真径との比 \\
$H / D$
\end{tabular} & 補正係数 & 備 \\
\hline 2.00 & 1.00 & $H / D$ がこの表に示す值の中間にある場 \\
1.75 & 0.98 & 合は, 補正係数は補完して求める。 \\
1.50 & 0.96 & \\
1.25 & 0.93 & \\
1.00 & 0.89 & \\
\hline
\end{tabular}

置を決めなければならない。また，構造的に大きな応力 が生じている部分からのコア採取はなるべくやめ，やむ をえず行う場合には構造物の補強を考慮しておかなけれ ばならない。

2）コアの形状，寸法は任意でよいが，粗骨材の最大 寸法の少なくとも 2 倍以上の直径の円柱がよい。高さも 直径の 2 倍に近いほどよい。直径と高さの比が $1: 2$ で ない場合は，表一6 による修正を行う必要がある。

3）コアの採取は，衝撃のあまりかからない機械によ るのがよい。ダイヤモンドドリルを用いるとよい。

4）採取された供試体は，完全な円柱の形状に成形し なければならない。円柱供試体の上下面部が構造物の表 面部等で, レイタンス等の弱点がある場合は, その部分 を切り取っておくのがよい。

5）供試体は 3 本以上採取し, 強度推定の精度を上げ
るのがよい。

6）比較用として，健全部からのコア採取をするのが よい。また, 構造物と同じ配合による供試体を作成し, 標準養生と現場養生とによる圧縮強度の相違についても 調べておくとよい。

コアの圧縮強度試験結果から問題がなければ，構造物 より資料を採取したコアの穴の部分に，構造物と同等以 上の強度を有するモルタル（膨張モルタルを用いるとよ い）を埋め, 表面を仕上げておけばよい。強度に問題が あれば，更に供試体の数を増して調べるか，次に述べる 載荷試験により構造物の全体の強度の検査を行い, 安全 性をチェックするとよい。

\section{（3）載荷試験による検査}

構造物全体の安全性を検查する目的で載荷試験を行う 場合がある (工事完了直後に載荷試験を行っておくと将 来の維持管理に役立つ)。

試験方法は，設計荷重（場合によってはその 1.5 倍 程度）を構造物に載荷し, 構造物の部材各部の応力, た わみ等を測定し, 設計計算値と比較して検討される。載 荷方法の詳細については, 一概に述べられないので省略 するが，これまで述べた検查結果と照らし合わせて, 総 合的に構造物の強度をチェックするとよい。 